\title{
Detection and characterization of heavy drizzle cells within subtropical marine stratocumulus using AMSR-E 89-GHz passive microwave measurements
}

\author{
M. A. Miller and S. E. Yuter \\ North Carolina State University, Department of Marine, Earth, and Atmospheric Sciences, Campus Box 8208, \\ Raleigh, NC 27695, USA
}

Correspondence to: M. A. Miller (mamille4@ncsu.edu)

Received: 2 May 2012 - Published in Atmos. Meas. Tech. Discuss.: 2 July 2012

Revised: 16 November 2012 - Accepted: 19 November 2012 - Published: 2 January 2013

\begin{abstract}
This empirical study demonstrates the feasibility of using 89-GHz Advanced Microwave Scanning Radiometer-Earth Observing System (AMSR-E) passive microwave brightness temperature data to detect heavily drizzling cells within subtropical marine stratocumulus. For the purpose of this paper, we define heavily drizzling cells as areas $\geq 6 \mathrm{~km} \times 4 \mathrm{~km}$ with $\mathrm{C}$-band $Z>0 \mathrm{dBZ}$; equivalent to $>0.084 \mathrm{~mm} \mathrm{~h}^{-1}$. A binary heavy drizzle product is described that can be used to determine areal and feature statistics of drizzle cells within the major marine stratocumulus regions. Current satellite liquid water path (LWP) and cloud radar products capable of detecting drizzle are either lacking in resolution (AMSR-E LWP), diurnal coverage (MODIS LWP), or spatial coverage (CloudSat). The AMSR-E 89-GHz data set at $6 \mathrm{~km} \times 4 \mathrm{~km}$ spatial resolution is sufficient for resolving individual heavily drizzling cells. Radiant emission at $89 \mathrm{GHz}$ by liquid-water cloud and precipitation particles from drizzling cells in marine stratocumulus regions yields local maxima in brightness temperature against an otherwise cloud-free background brightness temperature. The background brightness temperature is primarily constrained by column-integrated water vapor for moderate sea surface temperatures. Clouds containing ice are screened out. Once heavily drizzling pixels are identified, connected pixels are grouped into discrete drizzle cell features. The identified drizzle cells are used in turn to determine several spatial statistics for each satellite scene, including drizzle cell number and size distribution. The identification of heavily drizzling cells within marine stratocumulus regions with satellite data facilitates analysis of seasonal and regional drizzle cell
\end{abstract}

occurrence and the interrelation between drizzle and changes in cloud fraction.

\section{Introduction}

Marine stratocumulus clouds cover vast regions of the eastern subtropical oceans and are a source of net cooling in the Earth's radiation budget (Hartmann et al., 1992). The radiative characteristics of marine stratocumulus are closely tied to cloud fraction, which differs dramatically between regions of continuous unbroken cloud versus regions with mesoscale pockets of open cells (Stevens et al., 2005). Observational and modeling studies have implicated heavy drizzle cells in the transitions between closed- and open-cell mesoscale cloud structures (Stevens et al., 2005; van Zanten and Stevens, 2005; Comstock et al., 2007; Savic-Jovic and Stevens, 2008; Wang and Feingold, 2009; Wood et al., 2011a). These studies suggest that drizzle is a necessary but not sufficient condition for the formation of pockets of open cells. The spatial and temporal distributions of drizzle within marine stratocumulus clouds are hence key parameters of interest.

Cloud- and precipitation-induced perturbations in satellite-based high-frequency passive microwave observations are typically described as a function of ice scattering (Kidder and Vonder Haar, 1995). The emission by liquid water at $89 \mathrm{GHz}$ has been used previously in the retrieval of liquid water path (LWP) when cloud ice or precipitation ice is not present. Petty (1994, his Eq. 9) describes a method 
using $85.5 \mathrm{GHz}$ data from Special Sensor Microwave Imager (SSM/I) to estimate LWP as a function of the normalized polarization difference (Petty and Katsaros, 1990, 1992). This method was devised for general precipitation cases and was specific to SSM/I sensors. The Petty method also required an estimation of hypothetical clear-sky brightness temperature values. The calculation of clear-sky values can be challenging for regions of broad cloudiness, like stratocumulus regions, without relying on climatology data or data from multiple sensor platforms. Crewell and Lǒhnert (2003) used vertically pointing (upward) $90 \mathrm{GHz}$ radiometer data to improve the accuracy of retrieved LWP of cloud liquid water and drizzle.

In the absence of ice, satellite-observed $89-\mathrm{GHz}$ brightness temperatures are the net result of column-integrated emission and scattering of upwelling radiation by the ocean-surface, water vapor, and liquid hydrometeors. The variances in observed brightness temperature are primarily a function of the background ocean-surface emission (primarily related to sea surface temperature - SST - and wind speed), gas absorption, water vapor profile, beam filling, and LWP, including cloud and precipitable water (Westwater et al., 2001; Crewell and Lǒhnert, 2003; Greenwald et al., 2007; Horváth and Gentemann, 2007; Greenwald, 2009). Of these sources of emission, we expect that LWP will have the largest variance at spatial scales on the order of individual drizzle cells within marine stratocumulus.

A new satellite-based method to document drizzle cell occurrence within marine stratocumulus clouds can complement existing satellite observations, each of which has limitations. The key limitation of the Moderate Resolution Imaging Spectroradiometer (MODIS) Cloud Liquid Water Path product (King et al., 2003) is that it requires information from MODIS visible wavelength channels and is not available at night. For the purposes of this study, we refer to the MODIS Cloud Water Path as LWP. For stratocumulus observations, the two parameters should be the same and we use the terms interchangeably. While drizzle does occur in marine stratocumulus regions during daylight hours, more frequent and intense marine stratocumulus drizzle typically occurs at night when LWP values are higher (Bretherton et al., 2004; Comstock et al., 2005; Sharon et al., 2006). Any method attempting to ascertain the regional characteristics of drizzle while excluding nighttime drizzle would miss the mode of the drizzle cell distribution and hence would not produce a robust representation of regional drizzle characteristics. Current passive microwave LWP products (Wentz and Meissner, 2000, 2004; Kida et al., 2009) have too coarse a spatial resolution $(14 \mathrm{~km} \times 8 \mathrm{~km})$ to adequately resolve small and intense drizzle cells, which are typically $1-10 \mathrm{~km}$ in horizontal dimension. The CloudSat radar (Stephens et al., 2002, 2008; Haynes and Stephens, 2007) has a minimum sensitivity of $-28 \mathrm{dBZ}$ and provides information on the vertical structure of clouds. CloudSat observations of cloud-top heights and the profile of reflectivity are important physical characteristics of marine stratocumulus. However, CloudSat's swath width of $1.4 \mathrm{~km}$ is not adequate to obtain information on the horizontal mesoscale organization of drizzle. The Tropical Rainfall Measuring Mission (TRMM) satellite's Precipitation Radar can only detect the very strongest drizzle cells that have radar reflectivities above the radar's minimum sensitivity of $17 \mathrm{dBZ}$ at $5 \mathrm{~km} \times 5 \mathrm{~km}$ spatial resolution (Kummerow et al., 1998).

The goal of this study is to use empirical data to demonstrate the feasibility of using 89-GHz Advanced Microwave Scanning Radiometer-Earth Observing System (AMSR-E) (Kawanishi et al., 2003) passive microwave brightness temperature data (Ashcroft and Wentz, 2006) to detect heavily drizzling cells within marine stratocumulus. A binary heavy drizzle classification product is described that can be used to determine areal and feature statistics of drizzle cells within major marine stratocumulus regions.

\section{Methodology}

\subsection{Motivation}

The Variability of the American Monsoon System (VAMOS) Ocean-Cloud Atmospheric-Land Study (VOCALS) Regional Experiment (REx) (Wood et al., 2011b), which took place in the southeastern Pacific Ocean during October and November 2008, provided an opportunity for the intercomparison of satellite- and surface-based measurements of marine stratocumulus clouds and drizzle. The C-band wavelength radar on the National Oceanic and Atmospheric Administration (NOAA) ship Ronald H. Brown scanned a 120-km-diameter circle centered on the ship with a minimum sensitivity of radar reflectivity $\approx 0 \mathrm{dBZ}$. The mesoscale structures of heavy drizzle in the region scanned by the radar can be compared to those retrieved by various satellite algorithms.

Figure 1 shows collocated observations near $21^{\circ} \mathrm{S}$ and $85^{\circ} \mathrm{W}$ within the southeast Pacific stratocumulus region from MODIS LWP, AMSR-E LWP (Wentz and Meissner, 2000, 2004), AMSR-E $89-\mathrm{GHz}$ horizontally polarized $(H)$ brightness temperature $\left(T_{89 \mathrm{H}}\right)$, and NOAA ship radar's C-band radar reflectivity. The horizontally polarized $89-\mathrm{GHz}$ brightness temperature channel is used in this study because it contains less noise than the vertically polarized channel. There is also a larger dynamic range of surface emissivities for horizontal polarizations in the microwave band, which allows for better resolving of surface features (Jones and Vonder Haar, 1997). In Fig. 1d, cells with radar reflectivities $(Z)$ greater than $0 \mathrm{dBZ}$ indicate the presence of heavy drizzle. The MODIS LWP data clearly capture these heavily drizzling cells, which are characterized by LWP values $\geq 200 \mathrm{~g} \mathrm{~m}^{-2}$. These same cells are also noticeable in the AMSR-E LWP data by their relatively high LWP values and gradients at the cell edges. The heavy drizzle classification 

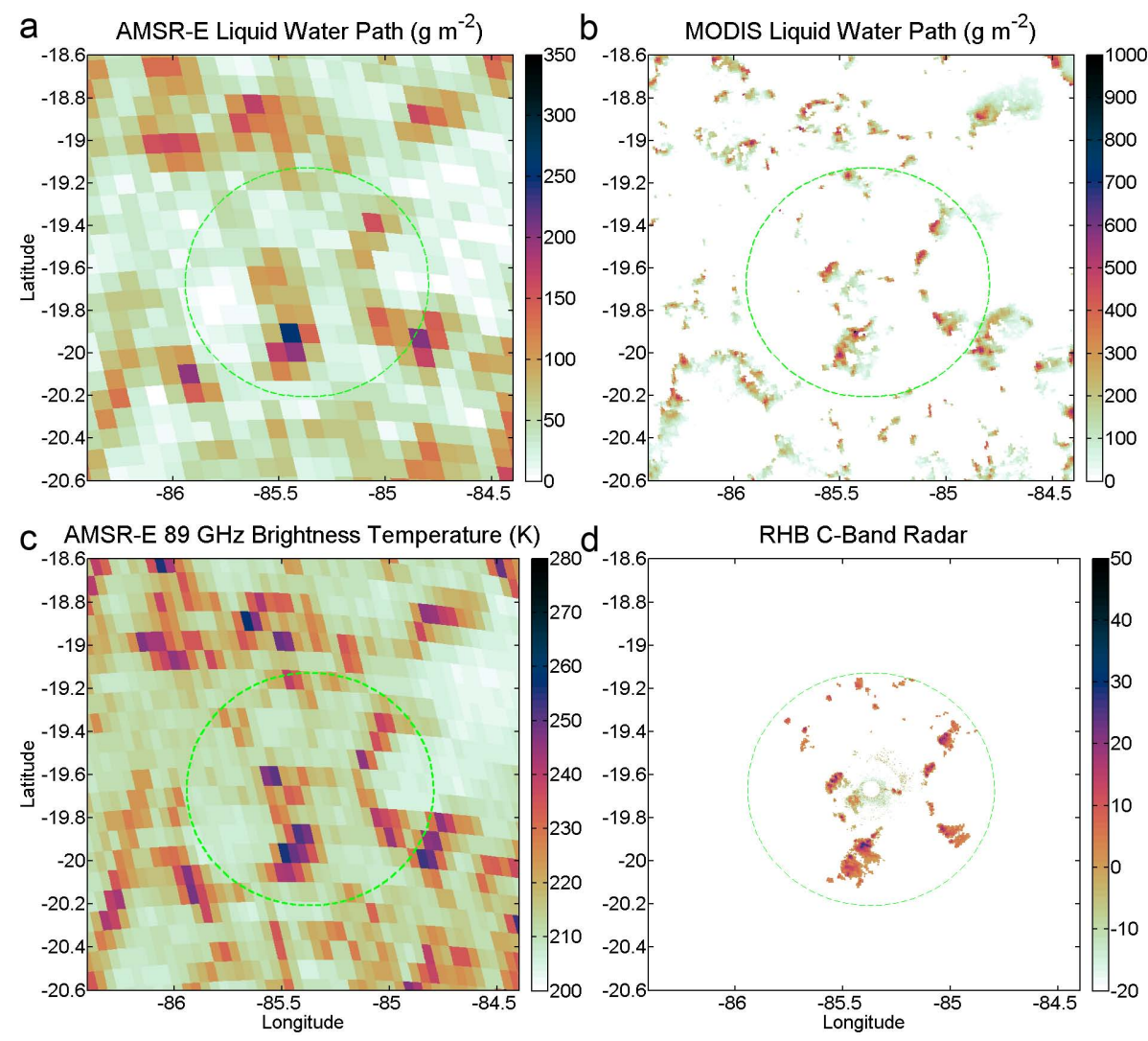

Fig. 1. Detailed comparison among (a) AMSR-E LWP, (b) MODIS Level 2 Cloud Water Path, (c) AMSR-E Level 2 89-GHz brightness temperature, and (d) C-band ship-borne radar reflectivity data (dBZ) obtained at 19:36 UTC on 27 October 2008 in the southeast Pacific during VOCALS experiment. The $60 \mathrm{~km}$ radius range ring from the radar is overlaid on each image. In order to highlight gradients in LWP, the dynamic range of the color scales differs between (a) and (b).

algorithm described in this paper stems from the observations in Fig. 1c. Drizzle cells corresponding to those observed by the C-band radar are evident as distinct local maxima in $T_{89 \mathrm{H}}$ (Fig. 1c). Since strong drizzle cells with $Z>0 \mathrm{dBZ}$ are usually between 1 and $10 \mathrm{~km}$ in scale, these features are more distinct in the finer-resolution $T_{89 \mathrm{H}}$ data at $6 \mathrm{~km} \times 4 \mathrm{~km}$ spatial resolution compared with the AMSR-E LWP product at $14 \mathrm{~km} \times 8 \mathrm{~km}$. The disadvantage of an $89-\mathrm{GHz}-$ based method is that it will not work where clouds containing ice are present. The inversion-topped boundary layers in the subtropical regions constrain marine stratocumulus cloud-top altitudes to well below the $0^{\circ} \mathrm{C}$ level, precluding the existence of drizzling clouds containing ice, and making these clouds a prime candidate for the exploitation of $89-\mathrm{GHz}$ emission. Within marine stratocumulus regions characterized by strong inversions, any middle level or high level ice clouds can be easily distinguished from liquid-phase clouds by their cloudtop temperatures.

\subsection{Binary heavy drizzle cell classification algorithm}

For the purpose of this paper, we define heavily drizzling cells as areas $\geq 6 \mathrm{~km} \times 4 \mathrm{~km}$ with C-band $Z>0 \mathrm{dBZ}$.
Using the cloud base $Z-R$ relationship from Comstock et al. (2004), $0 \mathrm{dBZ}$ is equivalent to $0.084 \mathrm{~mm} \mathrm{~h}^{-1}$. C-band $Z>0 \mathrm{dBZ}$ is approximately equivalent to $\mathrm{LWP} \approx 200 \mathrm{~g} \mathrm{~m}^{-2}$ (Wood et al., 2011a). This definition corresponds to the subset of drizzle features within marine stratocumulus with sufficiently high drizzle intensity that precipitation usually reaches the surface (Comstock et al., 2005). A variety of independent studies suggest that LWP $\geq 200 \mathrm{~g} \mathrm{~m}^{-2}$ is a reasonable threshold to identify heavy drizzle. Ship-based upwardlooking microwave radiometer data from the EPIC experiment in 2001 (Bretherton et al., 2004) show that there is a dramatic increase in the frequency of occurrence of heavy drizzle ( $>0 \mathrm{dBZ}$ ) for LWP values $\geq 200 \mathrm{~g} \mathrm{~m}^{-2}$ (Zuidema et al., 2005). Fifty percent of drizzle and $90 \%$ of heavy drizzle occurred when LWP was $\geq 200 \mathrm{~g} \mathrm{~m}^{-2}$ (Zuidema et al., 2005). A survey of stratocumulus regions using CloudSat conducted by Leon et al. (2008) showed that 80 to $95 \%$ of observations with a LWP value of $200 \mathrm{~g} \mathrm{~m}^{-2}$ were drizzling, with the frequency of drizzle increasing as LWP increased. A similar study by Kubar et al. (2009) using CloudSat also shows that approximately $90 \%$ of non-drizzling clouds in the southeast Pacific have a LWP less than $200 \mathrm{~g} \mathrm{~m}^{-2}$. 

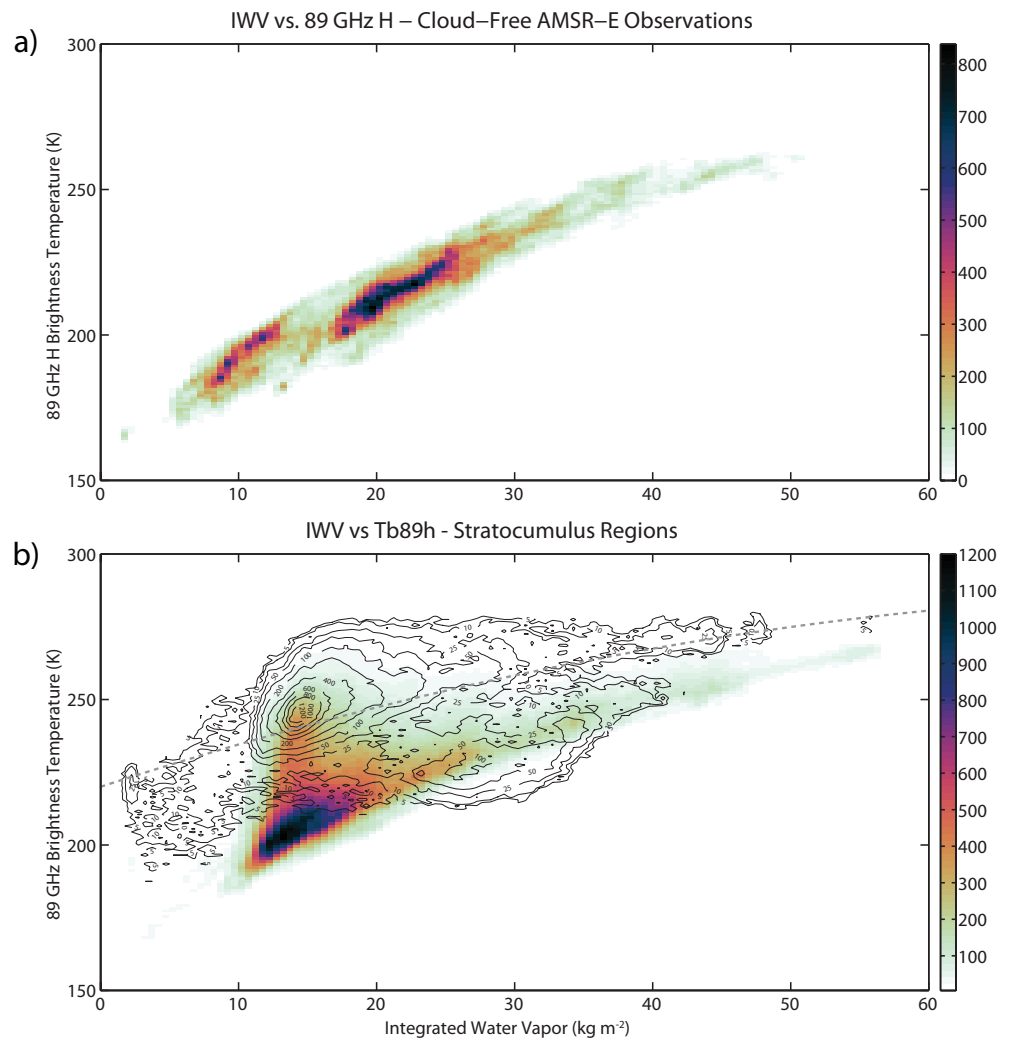

Fig. 2. (a) Scatter density plot of IWV versus $T_{89 \mathrm{H}}$ for cloud-free AMSR-E pixels from randomly selected scenes between $60^{\circ} \mathrm{N}$ and $60^{\circ} \mathrm{S}$ latitude. (b) Scatter density plot of IWV versus $T_{89 \mathrm{H}}$ for 4409366 pixels from 45 randomly selected marine stratocumulus scenes containing detectable drizzle. The contours denote the counts for the subset of points with LWP values $\geq 200 \mathrm{~g} \mathrm{~m}^{-2}$. The dashed grey line denotes the threshold curve for drizzle classification.

O'Conner et al. (2005) used a combination of radar and lidar to study Atlantic stratocumulus. Their data show significant increases in drizzle rain rates when LWP values spike above $200 \mathrm{~g} \mathrm{~m}^{-2}$. Although our algorithm identifies only the larger, heavily drizzling cells, it is an important contribution in mapping the global occurrence of drizzle within marine stratocumulus and its interrelations with changes in cloud fraction (de Szoeke et al., 2010).

We sidestep the complexities of evaluating drizzle based on a quantitative estimation of LWP by instead creating a binary heavy drizzle detection product based on a backgroundadaptive threshold of $T_{89 \mathrm{H}}$. Unlike the global MODIS LWP and AMSR-E LWP products, our heavy drizzle product is only applicable to geographic areas with strong inversions and persistent marine stratocumulus clouds. Our binary drizzle detection product complements, rather than replaces, MODIS LWP and AMSR-E LWP algorithms.

\subsubsection{Drizzle detection against a variable background}

Marine stratocumulus clouds can cover areas as large as $30^{\circ}$ of latitude and $25^{\circ}$ of longitude. One would not expect the background clear-sky brightness temperature to be uniform across such large areas or among the marine stratocumulus regions (e.g., southeast Pacific, southeast Atlantic, northeast Pacific, and northeast Atlantic). An adaptive method is needed for determining the background, cloud-free, brightness temperatures.

Figure 2a shows the strong correlation between AMSRE IWV (Wentz and Meissner, 2004) and AMSR-E $T_{89 \mathrm{H}}$ for a data set of more than 285000 cloud-free AMSR-E pixels randomly distributed in space and time between $60^{\circ} \mathrm{N}$ and $60^{\circ} \mathrm{S}$ latitude. Cloud-free pixels were defined as pixels with a cloud fraction $<0.01$ for MODIS MYD06 L2 data interpolated to match the resolution of the AMSR-E 89-GHz brightness temperature product. According to Petty's (1994) Eqs. (5e), (5f), and (5g), much of the remaining variation in $T_{89 \mathrm{H}}$ - that is, the range of $T_{89 \mathrm{H}}$ values for a given IWV value - can be explained as a function of wind speed. While wind speed is important to precisely estimate cloud-free brightness temperature, we found that including wind data as part of our detection algorithm produced a negligible improvement, and we did not include it in our method.

Liquid phase cloud, drizzle, and cloud-free pixels are all included in the scatter density plot of AMSR-E IWV versus AMSR-E $T_{89 \mathrm{H}}$ data (Fig. $2 \mathrm{~b}$ ) obtained within marine stratocumulus regions in the southeast Pacific, southeast 
Atlantic, and northeast Pacific mostly during months of peak stratocumulus frequencies: September and October for the Southern Hemisphere regions and June for the northeast Pacific. The most noticeable difference between the clear-sky and marine stratocumulus distributions is that the one for the stratocumulus regions is "two-pronged". One branch of the distribution is similar to that of the cloud-free pixels in Fig. 2a. The other branch has higher values of $T_{89 \mathrm{H}}$ for a given IWV value and corresponds to cloudy and drizzling pixels. The number of pixels with AMSR-E LWP $\geq 200 \mathrm{~g} \mathrm{~m}^{-2}$ for each pair of $T_{89 \mathrm{H}}$ and IWV values is shown as contours on top of the shaded scatter density plot. The relative values and shape of the contoured distribution are more important than the absolute magnitudes of the contours, which are a function of the size of this particular data set $\left(\approx 4.4 \times 10^{6}\right.$ pixels $)$. Of particular note is the local maximum in number of pixels with LWP $\geq 200 \mathrm{~g} \mathrm{~m}^{-2}$ located at IWV $\approx 15 \mathrm{~kg} \mathrm{~m}^{-2}$ and $T_{89 \mathrm{H}} \approx 245 \mathrm{~K}$.

Drizzling marine stratocumulus will emit more radiant energy and have a higher $T_{89 \mathrm{H}}$ than nearby cloud-free and cloudy non-drizzling areas. Based on this physical principle, we can estimate an offset in $T_{89 \mathrm{H}}$ as a function of IWV that separates drizzling from non-drizzling pixels. We start with an empirically derived curve fit between the cloud-free $T_{89 \mathrm{H}}$ and IWV values in Fig. 2a. The curve was then shifted to higher $T_{89 \mathrm{H}}$ values to separate the local maxima in number of points with AMSR-E LWP $\geq 200 \mathrm{~g} \mathrm{~m}^{-2}$ from the rest of the distribution. Iterative comparison of the resulting binary heavy drizzle classification product with either ship radar data from the VOCALS project or with AMSR-E LWP and MODIS LWP data for multiple cases from different stratocumulus regions allowed us to further refine the position of the curve. The exact position of the curve is somewhat subjective. Our goal was to find a curve that worked consistently among different marine stratocumulus geographic regions and would err on the side of underestimating the number of heavy drizzle pixels. The resulting empirically derived $T_{89 \mathrm{H}}$ threshold for classifying an AMSR-E pixel as drizzle or non-drizzle as a function of IWV is

$T_{89 \mathrm{H}, \text { threshold }}=-0.008875(\mathrm{IWV})^{2}+1.542(\mathrm{IWV})+220$

where $T_{89 \mathrm{H} \text {,threshold }}$ is the threshold value in $\mathrm{K}$ and IWV is the vertically integrated water vapor value in $\mathrm{kg} \mathrm{m}^{-2}$.

\subsubsection{Algorithm application}

The inputs to the algorithm are AMSR-E 89-GHz brightness temperatures, AMSR-E IWV (AMSR-E L2 Ocean; $14 \times 8 \mathrm{~km}$ pixel footprint), MODIS cloud-top temperature (MYD06L2; $5 \mathrm{~km}$ resolution), and AMSR-E SST (AMSRE L2 Ocean; $51 \times 30 \mathrm{~km}$ pixel footprint). All products are interpolated to match the $6 \mathrm{~km} \times 4 \mathrm{~km}$ AMSR-E $89-\mathrm{GHz}$ pixels. In the first step, pixels are removed from consideration based on cloud-top temperature and SST. Pixels with cloud-top temperatures less than $273 \mathrm{~K}$ were classified as non-drizzle to remove ice-phase cloud. Pixels with SST values less than $14^{\circ} \mathrm{C}$ and greater than $30^{\circ} \mathrm{C}$ are also classified as non-drizzle to reduce contamination from nonstratocumulus features that can be observed in scenes along the boundaries of stratocumulus regions. For the remaining pixels, the IWV value is converted to $T_{89 \mathrm{H} \text {,threshold }}$ using Eq. (1). If the pixel's $T_{89 \mathrm{H}}$ is greater than the $T_{89 \mathrm{H} \text {,threshold }}$ for that pixel, it is identified as heavy drizzle. The identification of discrete contiguous areas of detected drizzle is done using standard connected component algorithms for raster data (Rosenfeld and Pfaltz, 1966; Haralick and Shapiro, 1992). Once the discreet drizzle features are identified, several statistics can be calculated, including, but not limited to, cell area, aspect ratio, orientation, and frequency of occurrence per unit area.

\subsubsection{Caveats}

The algorithm was designed with the intention of identifying heavy drizzle in marine stratocumulus regions with largescale subsidence and shallow boundary layers such as those found off the western coasts of the Americas, Africa, and the Canary Islands. The algorithm was not intended for drizzle classification in thermally driven areas of stratocumulus (cold air outbreaks) more common to high latitude oceans, nor has it been tested in these areas. There is a potential for misclassification of drizzle in cases where the environmental properties lie outside the implicit climatology used in the empirical derivation. Anomalously high winds or atypical cloud properties could yield a skewed relationship between IWV and $T_{89 \mathrm{H}}$, which would lead to misclassification. However, the climatology of marine stratocumulus regions is such that these cases should be rare occurrences.

Classification error due to beam filling is an obvious concern and a key reason why we chose to err on the side of underestimating heavy drizzle areas. The ship C-band radar data during VOCALS show that most drizzle features with $Z>0 \mathrm{dBZ}$ have an area of approximately one $T_{89 \mathrm{H}}$ pixel $(6 \mathrm{~km} \times 4 \mathrm{~km})$ or larger. Based on EPIC data, Comstock et al. (2007) found that heavy drizzle events coincide with the presence of drizzle cells $>20 \mathrm{~km}^{2}$. Cloud and radiation model simulations by Lafont and Guillemet (2004) suggest that $89-\mathrm{GHz}$ brightness temperature values for stratiform clouds decrease as sub-pixel cloud fraction decreases. The effect increases as a function of LWP since higher LWP clouds contribute more to the observed brightness temperature than low LWP clouds. Cloud homogeneity and 3-D beam effects can also impact $89-\mathrm{GHz}$ brightness temperature estimations. The Lafont and Guillemet (2004) study suggests that heavy drizzle is most likely to be missed by our algorithm when the drizzle features have an area $\approx 80 \%$ or less than the $6 \mathrm{~km} \times 4 \mathrm{~km}$ footprint of the $T_{89 \mathrm{H}}$ data. 

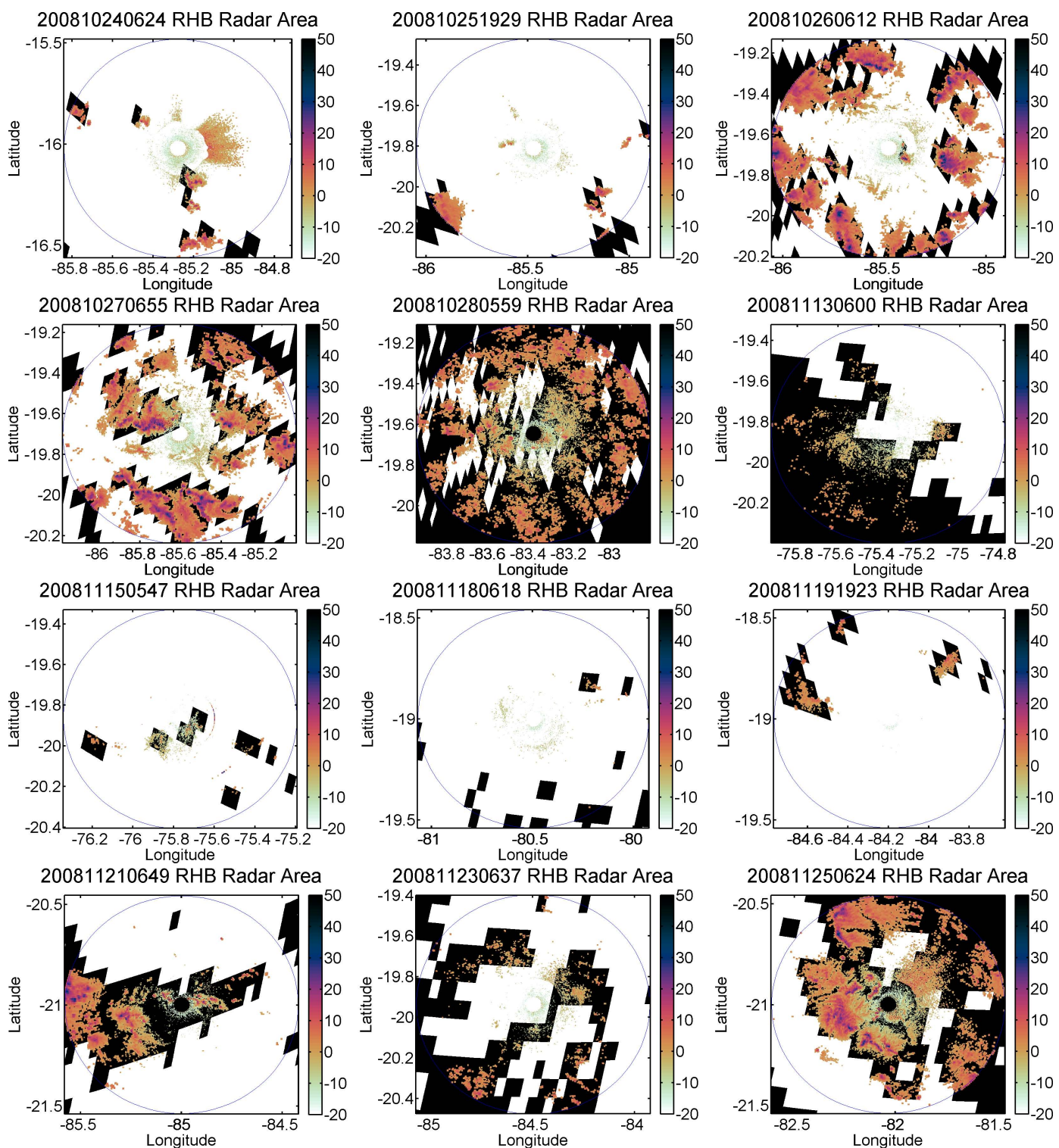

Fig. 3. C-band radar reflectivity data (dBZ) from the NOAA ship Ronald H. Brown, collected during the VOCALS project during October and November 2008, overlaid atop the $89-\mathrm{GHz}$-based binary heavy drizzle classification product. The black areas are the drizzle areas as classified by the binary heavy drizzle classification algorithm. The blue circle represents the maximum range of the radar.

\section{Evaluation}

\subsection{Comparison with VOCALS ship-based radar data}

Drizzle detection from 12 AMSR-E overpasses is compared with coincident $\mathrm{C}$-band radar data from the NOAA ship Ronald H. Brown collected during the VOCALS project (Fig. 3). The radar data are overlaid atop the binary heavy drizzle classification product. In each case, the drizzle classification algorithm captures the mesoscale structure of the drizzle observed. These 12 images display all the AMSR$\mathrm{E}$ and NOAA ship radar coincidences where drizzle was present in the ship radar volume during the VOCALS campaign. Some of the ship radar data obtained near the South American coast were contaminated with second-trip echoes and are excluded.

Table 1 summarizes the hit, miss, and false alarm rates for the drizzle detection in Fig. 3. The radar data were linearly interpolated to the scale of the drizzle detection product in order to calculate the hit, miss, and false alarm statistics. The average hit rate for the 12 scenes in Fig. 3 was $76.8 \%$ with an average miss rate of $2.2 \%$ and a false alarm rate of $21 \%$. The Heidke skill score is 0.385 . 


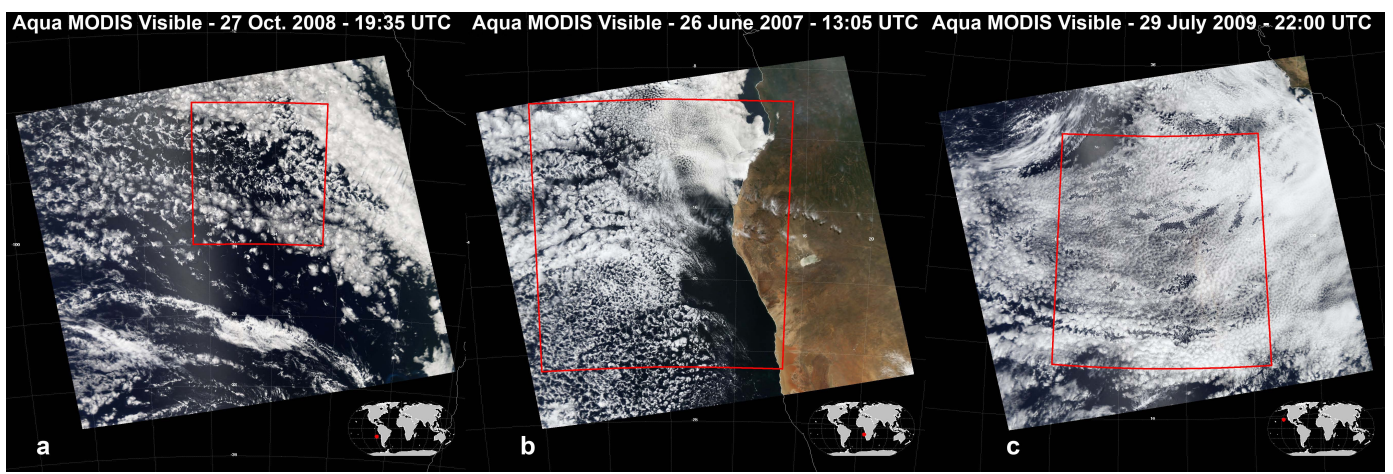

Fig. 4. Aqua MODIS visible quick-look imagery for the areas in Figs. 7, 9, and 10 from left to right (http://modis-atmos.gsfc.nasa.gov/ IMAGES/index_myd021 km.html).(a) is for the southeast Pacific on 27 October 2008 at $\approx 19: 35$ UTC. (b) is for the southeast Atlantic on 26 June 2007 at $\approx 13: 05$ UTC. (c) is for the northeast Pacific on 29 July 2009 at $\approx 22: 00$ UTC. The red boxes denote the areas of interest for the scenes in question.

Table 1. Summary of hit, miss, and false alarm rates for 12 scenes in Fig. 3.

\begin{tabular}{lrrr}
\hline & Minimum (\%) & Average (\%) & Maximum (\%) \\
\hline Hit rate & 43.9 & 76.8 & 98.4 \\
Miss rate & 0.0 & 2.2 & 9.0 \\
False alarm rate & 0.9 & 21.0 & 54.0 \\
\hline
\end{tabular}

\subsection{Comparison among satellite algorithms}

We compare our binary heavy drizzle detection algorithm to the well-established MODIS LWP and AMSR-E LWP products in daylight scenes containing marine stratocumulus from the southeast Pacific, the southeast Atlantic, and the northeast Pacific (Figs. 4-7, and Table 2). The comparison uses both the quantitative AMSR-E LWP and MODIS LWP data as well as two derived binary products based on AMSRE LWP and MODIS LWP values $\geq 200 \mathrm{~g} \mathrm{~m}^{-2}$ (Figs. 5-7). We recognize that heterogeneous beam filling means that a $200 \mathrm{~g} \mathrm{~m}^{-2}$ threshold applied to the $1 \mathrm{~km} \times 1 \mathrm{~km}$ resolution MODIS LWP product is not equivalent to a $200 \mathrm{~g} \mathrm{~m}^{-2}$ threshold applied to the $14 \mathrm{~km} \times 8 \mathrm{~km}$ resolution AMSRE LWP product. Ideally, we should use a lower threshold for the coarser-resolution AMSR-E LWP. Such a calculation would require quantitative MODIS LWP data within areas with low cloud fraction (regions of open cells) where the MODIS algorithm is known to have large uncertainties (Seethala and Horváth, 2010). For our purposes, application of a $200 \mathrm{~g} \mathrm{~m}^{-2}$ threshold to AMSR-E LWP will provide a robust underestimate of the heavily drizzling area compared to MODIS LWP. Similarly, our 89-GHz brightness temperature product will underestimate total drizzle area compared to the higher spatial resolution MODIS LWP assuming that individual drizzle elements have an area equal to or larger than the $6 \mathrm{~km} \times 4 \mathrm{~km}$ pixel size of the $89-\mathrm{GHz}$ channel.
Microwave and optical methods of estimating LWP generally agree with each other and perform well for marine stratocumulus regions (Lin and Rossow, 1994; Borg and Bennartz, 2007). More specifically, Seethala and Horváth (2010) state that AMSR-E and MODIS estimations of LWP agree best for stratocumulus regions and for other overcast regions when cloud fraction values are greater than 0.9. Within high cloud fraction conditions of marine stratocumulus regions, they found correlations up to 0.95 between AMSR-E LWP and MODIS LWP. For lower cloud fraction values, AMSR-E overestimates domain-mean LWP compared to MODIS. The changes in relative performance as a function of cloud fraction are likely a result of 3-D cloud effects, differences in the spatial resolution of the two products, and beam filling uncertainties.

Co-registered $89-\mathrm{GHz}$ brightness temperature data, our 89-GHz-based binary detection product, AMSR-E LWP, and MODIS LWP data are shown in Figs. 5-7. Figure 5 shows an area over the southeast Pacific on 27 October 2008. Satellite data from a scene with drizzle over the southeast Atlantic off the coast of Africa for 26 June 2007 are shown in Fig. 6. There are some high, mostly transparent, cirrus clouds in this scene with cloud-top temperatures $<273 \mathrm{~K}$ in a southwest to northeast strip at approximately $23^{\circ} \mathrm{S}$ latitude. The marine stratocumulus clouds common to this region have never been the subject of a major field observation campaign. Satellite data for an area over the northeast Pacific for 29 July 2009 that contains drizzle are shown in Fig. 7. This scene is a complex example with a strong SST gradient. In the southern half of this scene, $89-\mathrm{GHz}$ brightness temperatures are higher compared to the other examples in part because of higher SST and IWV values.

The example scenes in Figs. 5-7 illustrate better correspondence of the 89-GHz-based binary detection product to MODIS LWP than qualitative AMSR-LWP. In each example, the finer spatial resolution of $89-\mathrm{GHz}$ brightness temperatures compared to AMSR-E LWP permits detection of 

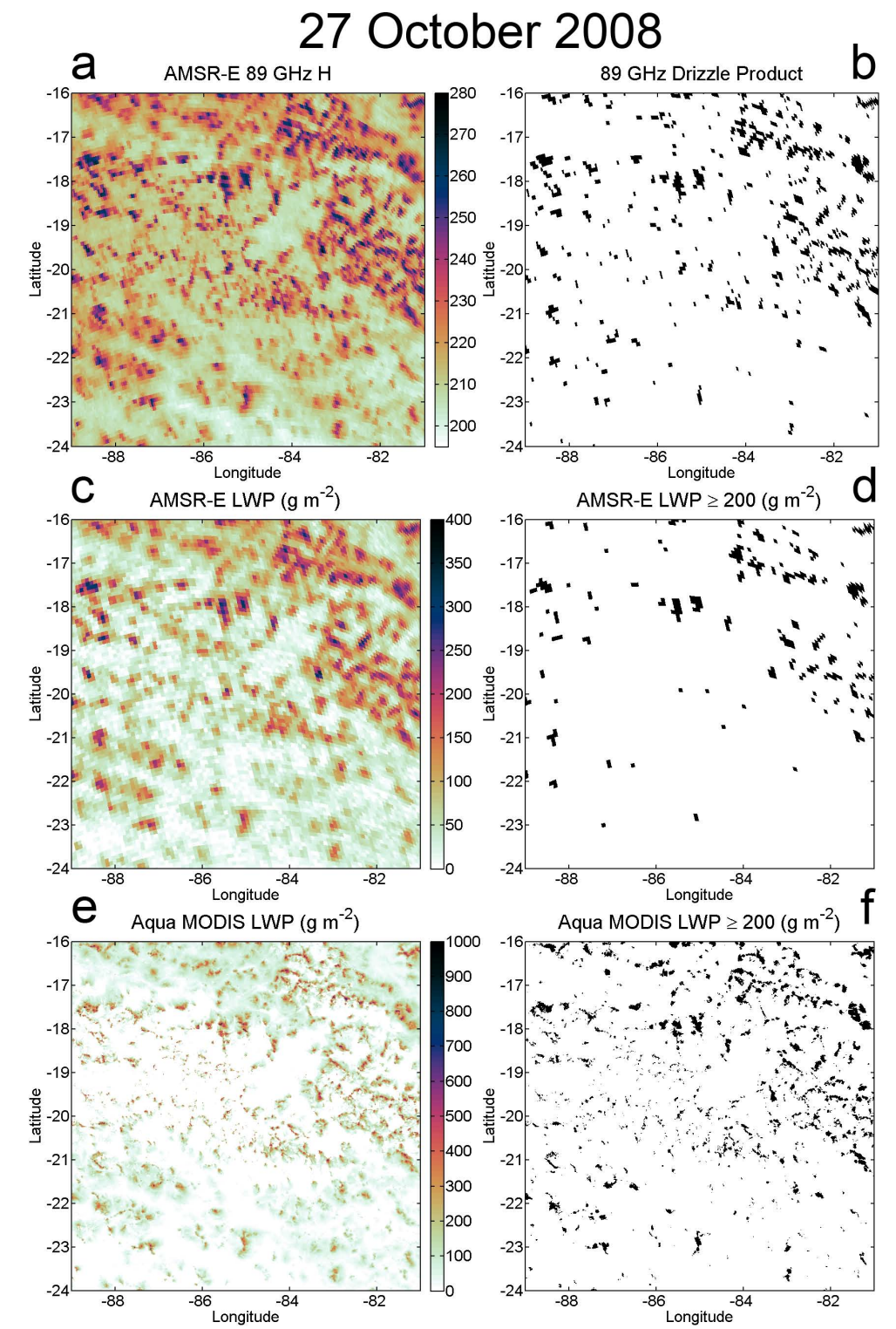

Fig. 5. Drizzle information for the southeast Pacific on 27 October 2008 at $\approx 19: 35$ UTC. (a) is AMSR-E horizontally polarized 89-GHz brightness temperature from the L2A brightness temperature product. (c) is AMSR-E LWP from the L2_Ocean product. (e) is the Aqua MODIS daytime mean cloud water path from the MYD06_L2 product. (b) is the 89-GHz-based binary heavy drizzle classification field where black indicates drizzle. (d) is a binary field where black indicates AMSR-E LWP $\geq 200 \mathrm{~g} \mathrm{~m}^{-2}$. (f) is a binary field where black indicates MODIS LWP $\geq 200 \mathrm{~g} \mathrm{~m}^{-2}$.

smaller drizzle cells. The wider range of drizzle cell sizes detected by the $89-\mathrm{GHz}$-based method aids in determining the mesoscale spatial distribution of the drizzle. This mesoscale spatial structure of heavy drizzle is an important component in understanding the underlying physical processes (Comstock et al., 2007). Recall from Sect. 1, that the primary advantage of our algorithm is that it provides higher spatial resolution information than AMSR-E LWP at night, when drizzle is more intense and frequent, and when the MODIS LWP product is not available.
Another artifact of the difference in spatial resolution between AMSR-E $89 \mathrm{GHz}$ and MODIS LWP is that the coarser resolution $89-\mathrm{GHz}$ data will tend to slightly shift the size distribution of contiguous areas of drizzle toward larger areas. The impact of this artifact is illustrated in Fig. 8, which shows a histogram of discrete drizzle cell area from our 89GHz-based algorithm and MODIS LWP for the example scene from the southeast Pacific in Fig. 5. Although the total area identified by the 89-Ghz-based algorithm as drizzle is less than that from MODIS LWP, our algorithm detects contiguous drizzle cells $>400 \mathrm{~km}^{2}$, which are not present 


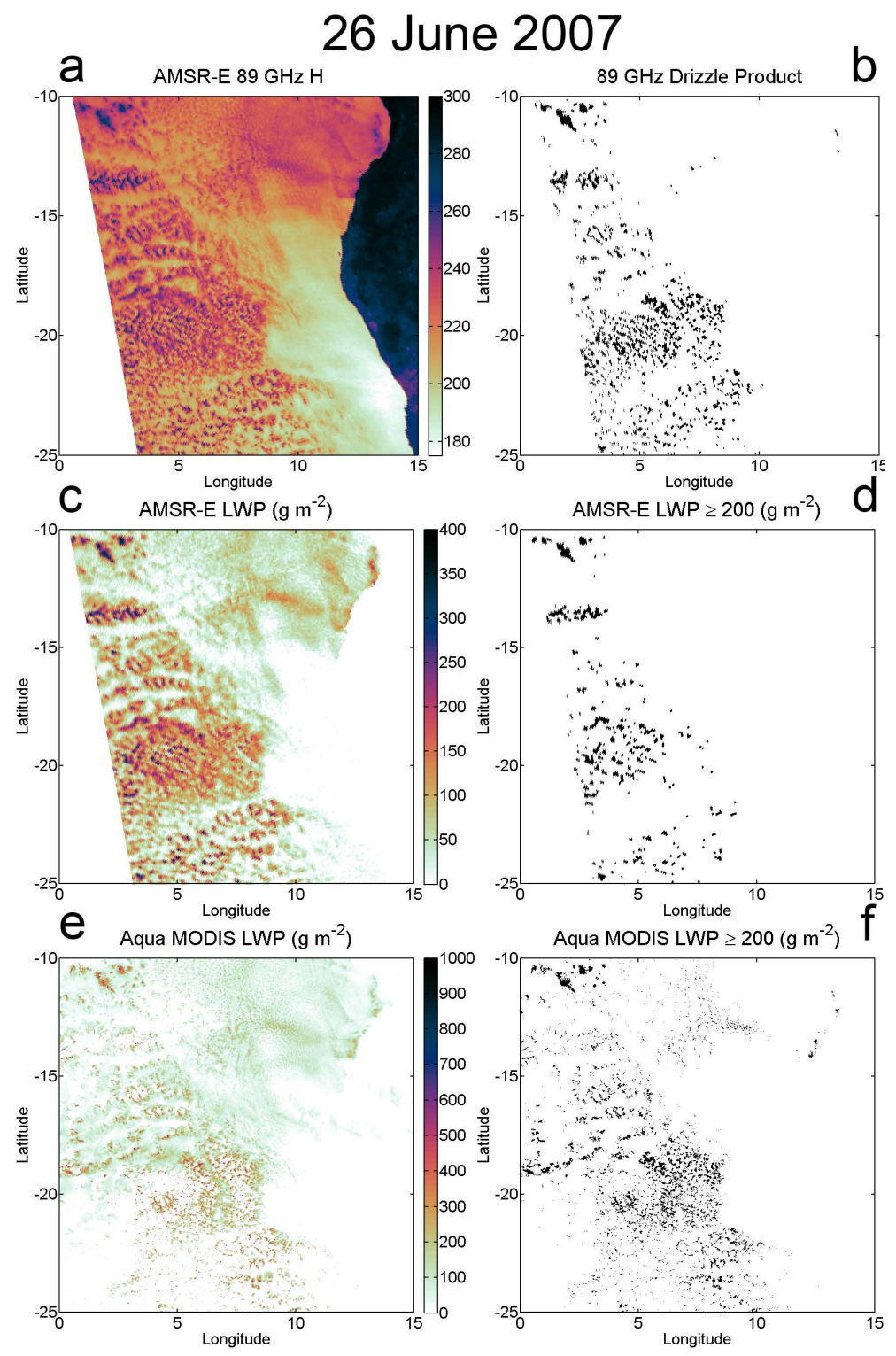

Fig. 6. Drizzle information for the southeast Atlantic on 26 June 2007 at $\approx 13: 05$ UTC. (a) is AMSR-E horizontally polarized 89-GHz brightness temperature from the L2A brightness temperature product. (c) is AMSR-E LWP from the L2_Ocean product. (e) is the Aqua MODIS daytime mean cloud water path from the MYD06_L2 product. (b) is the 89-GHz-based binary heavy drizzle classification field where black indicates drizzle. (d) is a binary field where black indicates AMSR-E LWP $\geq 200 \mathrm{~g} \mathrm{~m}^{-2}$. (f) is a binary field where black indicates MODIS LWP $\geq 200 \mathrm{~g} \mathrm{~m}^{-2}$.

in the MODIS LWP data. Beam filling causes our algorithm to overestimate the size of the largest contiguous cells. This shifting of the size distribution has to be taken into account when examining results from our algorithm.

Table 2 summarizes the drizzle area statistics for the different products in each scene. As expected, our binary heavy drizzle detection product identifies more drizzle area $(\approx 50 \%$ more) than the $200 \mathrm{~g} \mathrm{~m}^{-2}$ threshold applied to AMSRE LWP. The $200 \mathrm{~g} \mathrm{~m}^{-2}$ threshold applied to MODIS LWP yields the largest drizzle areas with the exception of the southeast Atlantic scene where the 89-GHz-based binary heavy drizzle product identified $\approx 7 \%$ more drizzle area. This discrepancy is likely due to sizes of the drizzle elements. The MODIS data panels in Fig. 5 illustrate that the drizzle elements are very small. We theorize that drizzle features that are a cluster of cells each smaller than the $6 \mathrm{~km} \times 4 \mathrm{~km} 89$ $\mathrm{GHz}$ pixel size are detected as one large mass. The result of this is that when there are many drizzle elements smaller than the 89-GHz pixel size, overestimation of area is possible with respect to MODIS data since the space between the small elements is also flagged as drizzle as part of an error due to resolution limitations. 

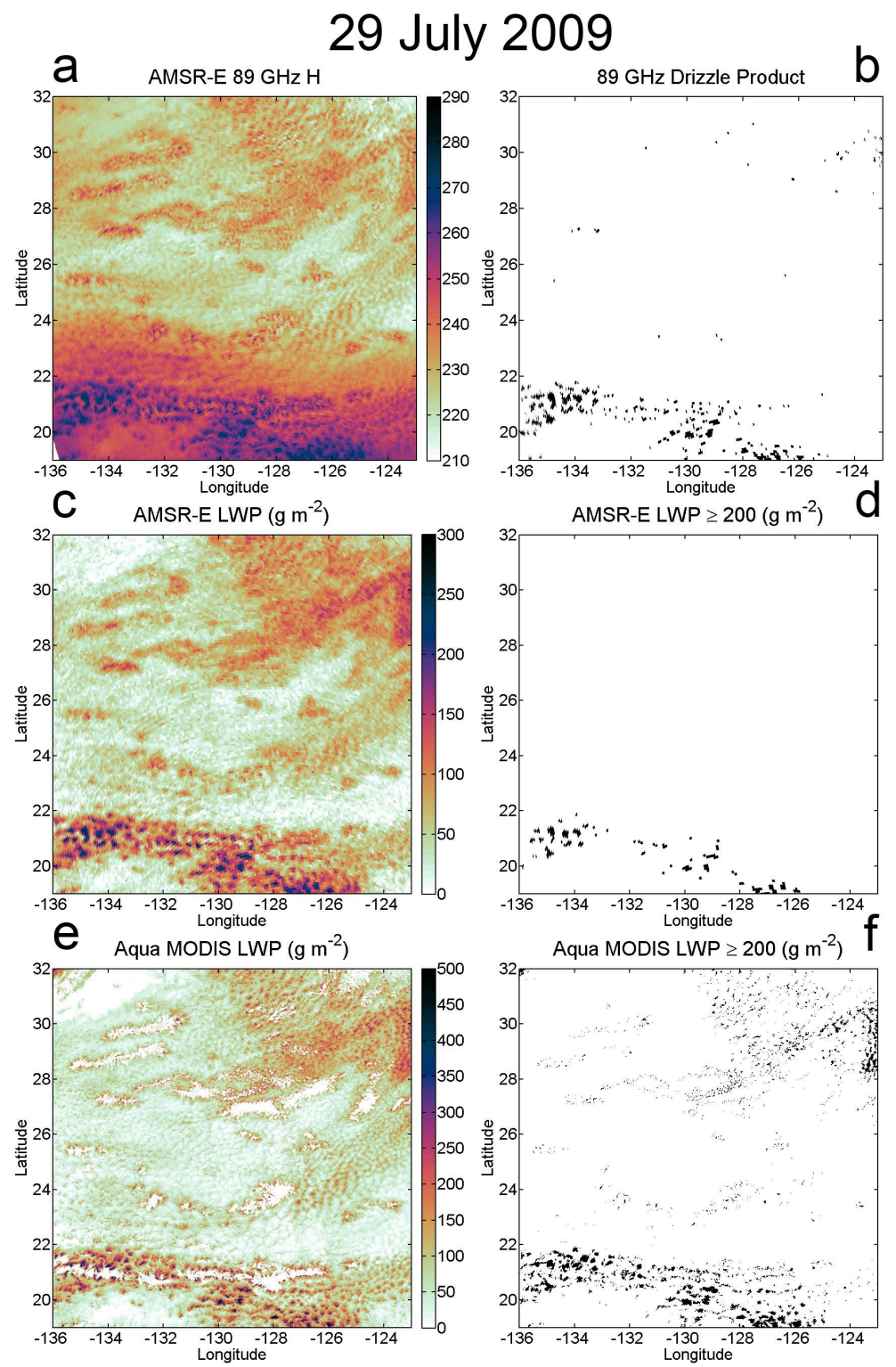

Fig. 7. Drizzle information for the northeast Pacific on 29 July 2009 at $\approx 22: 00$ UTC. (a) is AMSR-E horizontally polarized $89-G H z$ brightness temperature from the L2A brightness temperature product. (c) is AMSR-E LWP from the L2_Ocean product. (e) is the Aqua MODIS daytime mean cloud water path from the MYD06_L2 product. (b) is the 89-GHz-based binary heavy drizzle classification field where black indicates drizzle. (d) is a binary field where black indicates AMSR-E LWP $\geq 200 \mathrm{~g} \mathrm{~m}^{-2}$. (f) is a binary field where black indicates MODIS LWP $\geq 200 \mathrm{~g} \mathrm{~m}^{-2}$.

\section{Conclusions}

Drizzle plays a key role in the evolution of marine stratocumulus and the transitions between closed- and opencell states. The binary heavy drizzle classification product based on AMSR-E data described in this paper represents a new approach that provides additional information on the frequency of occurrence and spatial characteristics of drizzle. Current satellite methods are either lacking in resolution (AMSR-E LWP), night coverage (MODIS LWP), or the broad areal coverage (CloudSat) necessary to observe the horizontal mesoscale structure of drizzling marine stratocumulus. Use of high-frequency passive microwave observations to detect drizzle in marine stratocumulus environments enables consistent observations at resolutions sufficient for resolving individual heavily drizzling cells and their mesoscale structure.

Emission by precipitation liquid water from drizzle cells in marine stratocumulus regions yields local maxima in brightness temperature in AMSR-E 89-GHz data. Co-located AMSR-E IWV data are used to determine an $89-\mathrm{GHz}$ 
Table 2. Summary of total drizzle areas for products for scenes from Sect. 3.

\begin{tabular}{llll}
\hline Date & 27 Oct 2008 & 26 Jun 2007 & 29 Jul 2009 \\
\hline Case Time (UTC) & $19: 35$ & $13: 05$ & $22: 00$ \\
Location & SE Pacific & SE Atlantic & NE Pacific \\
89-GHz drizzle area $\left(\mathrm{km}^{2}\right)$ & 23892 & 61259 & 14713 \\
AMSR-E drizzle area $\left(\mathrm{km}^{2}\right)$ & 12543 & 34243 & 6553 \\
MODIS drizzle area $\left(\mathrm{km}^{2}\right)$ & 31207 & 6553 & 44174 \\
Number of drizzle cells - 89 GHz & 246 & 527 & 222 \\
Number of drizzle cells - AMSR-E & 105 & 293 & 91 \\
Number of drizzle cells - MODIS & 1759 & 5894 & 6781 \\
Average cell size - 89 GHz $\left(\mathrm{km}^{2}\right)$ & 61.19 & 68.36 & 58.37 \\
Average cell size - AMSR-E $\left(\mathrm{km}^{2}\right)$ & 119.35 & 116.75 & 278.19 \\
Average cell size - MODIS $\left(\mathrm{km}^{2}\right)$ & 17.74 & 9.73 & 10.56 \\
\hline
\end{tabular}
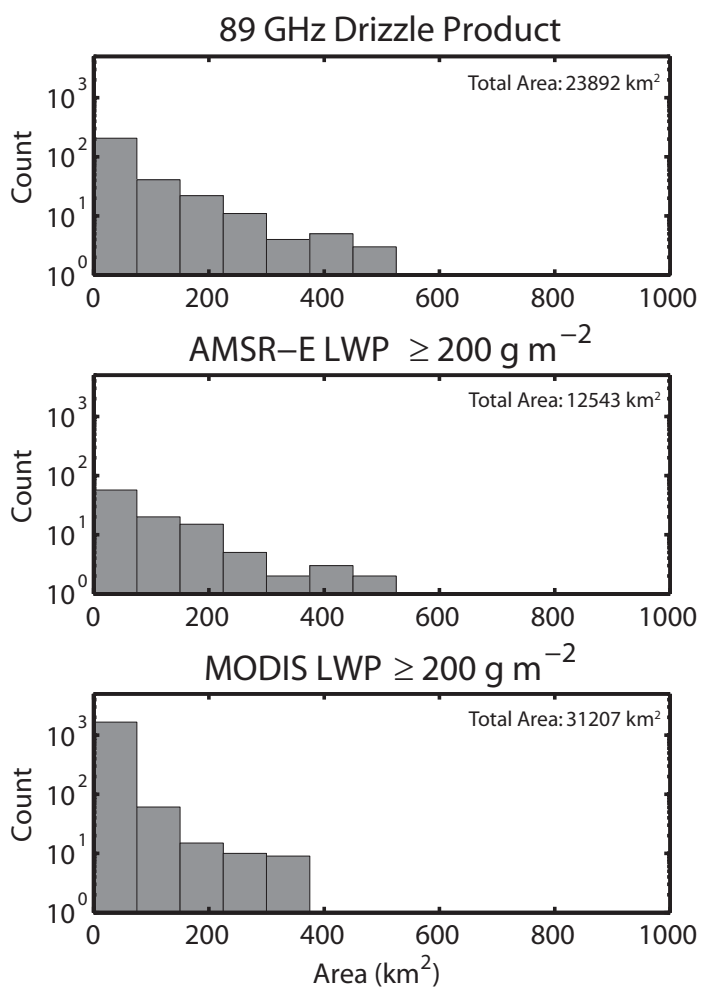

Fig. 8. Histograms comparing drizzle area calculated from the 89GHz-based binary heavy drizzle classification product, AMSRE LWP, and MODIS LWP for the time and region from Fig. 5. The upper panel is the area histogram for contiguous drizzle pockets detected using 89-GHz brightness temperature data. The middle panel is the area histogram for contiguous drizzle pockets defined as contiguous areas with AMSR-E LWP $\geq 200 \mathrm{~g} \mathrm{~m}^{-2}$. The lower panel is the area histogram for contiguous drizzle pockets, defined as contiguous areas with MODIS LWP $\geq 200 \mathrm{~g} \mathrm{~m}^{-2}$. The total area identified as drizzle is given for each product. Contiguous areas are identified based on 4-connectivity. background brightness temperature threshold to which these local maxima can be compared. Once drizzle is identified, standard connected-component algorithms are used to identify discrete drizzle cells and calculate various spatial statistics.

Even without an accompanying quantitative estimate of drizzle LWP, the satellite-based binary identification of heavy drizzle cells within marine stratocumulus regions will permit analysis of seasonal and regional drizzle cell occurrence and the interrelation between drizzle and changes in cloud fraction. Several characteristics of contiguous drizzle cell features can be documented: the number of drizzle cells per unit area, their sizes and shape, and the distances between cells. In ongoing work, we are using these properties as comparison metrics among the different marine stratocumulus regions. The information on marine stratocumulus drizzle from the $89-\mathrm{GHz}$-based drizzle detection algorithm will also provide an avenue for evaluation of numerical model parameterizations. Future work is planned for extending this methodology to the TRMM microwave radiometer $85.5 \mathrm{GHz}$ channel in order to provide data over the full diurnal cycle.

Acknowledgements. The authors would like to thank Robert Pincus and Casey Burleyson for their helpful reviews on draft versions of this manuscript.

This research was supported by NASA Earth and Space Science Fellowship NNX07AN71H, NOAA grant GC08-252b, and NASA EOS grant NNX11AE98G.

Edited by: A. Kokhanovsky 


\section{References}

Ashcroft, P. and Wentz, F.: AMSR-E/Aqua L2A Global Swath Spatially-Resampled Brightness Temperatures V002, Various dates, http://www.nsidc.org/data/amsre, National Snow and Ice Data Center, Boulder, Colorado, USA, 2006.

Borg, L. A. and Bennartz, R.: Vertical structure of stratiform marine boundary layer clouds and its impact on cloud albedo, Geophys. Res. Lett., 34, L05807, doi:10.1029/2006GL028713, 2007.

Bretherton, C. S., Uttal, T., Fairall, C. W., Yuter, S., Weller, R., Baumgardner, D., Comstock, K., and Wood, R.: The EPIC 2001 stratocumulus study, B. Am. Meteorol. Soc., 85, 967-977, 2004.

Comstock, K. K., Wood, R., Yuter, S. E., and Bretherton, C. S.: Reflectivity and rain rate in and below drizzling stratocumulus, Q. J. Roy. Meteorol. Soc., 130, 2891-2918, 2004.

Comstock, K. K., Bretherton, C. S., and Yuter, S. E.: Mesoscale variability and drizzle in southeast Pacific stratocumulus, J. Atmos. Sci., 62, 3792-3807, 2005.

Comstock, K., Yuter, S. E., Wood, R., and Bretherton, C. S.: The three-dimensional structure and kinematics of drizzling stratocumulus, Mon. Weather Rev., 135, 3767-3784, 2007.

Crewell, S. and Lǒhnert, U.: Accuracy of cloud liquid water path from ground-based microwave radiometry 2. Sensor accuracy and synergy, Radio Sci., 38, 8042, doi:10.1029/2002RS002634, 2003.

de Szoeke, S. P., Yuter, S. E., Zuidema, P., Fairall, C. W., and Brewer, W. A.: Ship-based observation of drizzling stratocumulus clouds from EPIC to VOCALS, CLIVAR Exchanges, 15, 1113, 2010.

Greenwald, T. J.: A 2 year comparison of AMSR-E and MODIS cloud liquid water path observations, Geophys. Res. Lett., 36, L20805, doi:10.1029/2009GL040394, 2009.

Greenwald, T. J., L'Ecuyer, T. S., and Christopher, S. A.: Evaluating specific error characteristics of microwave derived cloud liquid water products, Geophys. Res. Lett., 34, L22807, doi:10.1029/2007GL031180, 2007.

Haralick, R. M. and Shapiro, L. G.: Computer and Robot Vision, Addison-Wesley Longman Publishing Co., Inc, 1992.

Hartmann, D. L., Ockert-Bell, M. E., and Michelsen, M. L.: The effect of cloud type on Earth's energy balance: global analysis, J. Climate, 5, 1281-1304, 1992.

Haynes, J. and Stephens, G. L.: Tropical oceanic cloudiness and the incidence of precipitation: early results from CloudSat, Geophys. Res. Lett., 34, L09811, doi:10.1029/2007GL029335, 2007.

Horváth, Á. and Gentemann, C.: Cloud-fraction-dependent bias in satellite liquid water path retrievals of shallow, nonprecipitating marine clouds, Geophys. Res. Lett., 34, L22806, doi:10.1029/2007GL030625, 2007.

Jones, A. S. and Vonder Haar, T. H.: Retrieval of microwave surface emittance over land using coincident microwave and infrared satellite measurements, J. Geophys. Res., 102, 1360913626, doi:10.1029/97JD00797, 1997.

Kawanishi, T., Sezai, T., Ito, Y., Imaoka, K., Takeshima, T., Ishido, Y., Shibata, A., Miura, M., Inahata, H., and Spencer, R. W.: The Advanced Microwave Scanning Radiometer for the Earth Observing System (AMSR-E), NASDA's contribution to the EOS for global energy and water cycle studies, IEEE T. Geosci. Remote, 41, 184-194, 2003.
Kida, S., Shige, S., Kubota, T., Aonashi, K., and Okamoto, K.: Improvement of rain/no-rain classification methods for microwave radiometer observations over the Ocean Using a $37 \mathrm{GHz}$ Emission Signature, J. Meteorol. Soc. Jpn., 87A, 165-181, 2009.

Kidder, S. Q. and Vonder Haar, T. H.: Satellite Meteorology: An Introduction, Academic Press, 466 pp., doi:10.1016/B978-0-08057200-0.50007-9, 1995.

King, M. D., Menzel, W. P., Kaufman, Y. J., Tanre, D., Gao, B.-C., Platnick, S., Ackerman, S. A., Remer, L. A., Pincus, R., and Hubanks, P. A.: Cloud and aerosol properties, precipitable water, and profiles of temperature and water vapor from MODIS, IEEE T. Geosci. Remote, 41, 442-458, doi:10.1109/TGRS.2002.808226, 2003.

Kubar, T. L., Hartmann, D. L., and Wood, R.: Understanding the importance of microphysics and macrophysics for warm rain in marine low clouds, Part I: satellite observations, J. Atmos. Sci., 66, 2953-2972, doi:10.1175/2009JAS3071.1, 2009.

Kummerow, C., Barnes, W., Kozu, T., Shiue, J., and Simpson, J.: The Tropical Rainfall Measuring Mission (TRMM) sensor package, J. Atmos. Ocean. Tech., 15, 809-817, 1998.

Lafont, D. and Guillemet, B.: Subpixel fractional cloud cover and inhomogeneity effects on microwave beam-filling error, Atmos. Res., 72, 149-168, doi:10.1016/j.atmosres.2004.03.013, 2004.

Leon, D. C., Wang, Z., and Liu, D.: Climatology of drizzle in marine boundary layer clouds based on 1 year of data from CloudSat and Cloud-Aerosol Lidar and Infrared Pathfinder Satellite Observations (CALIPSO), J. Geophys. Res., 113, D00A14, doi:10.1029/2008JD009835, 2008.

Lin, B. and Rossow, W. B.: Observations of cloud liquid water path over oceans: optical and microwave remote sensing methods, J. Geophys. Res., 99, 20907-20927, doi:10.1029/94JD01831, 1994.

O'Connor, E. J., Hogan, R. J., and Illingworth, A. J.: Retrieving Stratocumulus Drizzle Parameters Using Doppler Radar and Lidar, J. Appl. Meteorol., 44, 14-27 doi:10.1175/JAM-2181.1, 2005.

Petty, G. W.: Physical retrievals of over-ocean rain rate from multichannel microwave imagery, Part II: algorithm implementation, Meteorol. Atmos. Phys., 54, 101-122, 1994.

Petty, G. W. and Katsaros, K. B.: Precipitation observed over the South China Sea by the Nimbus-7 Scanning Multichannel Microwave Imager during WMONEX, J. Appl. Meteorol., 29, 273 287, 1990.

Petty, G. W. and Katsaros, K. B.: Nimbus 7 SMMR precipitation observations calibrated against surface radar during TAMEX, J. Appl. Meteorol., 31, 489-505, 1992.

Rosenfeld, A. and Pfaltz, J. L.: Sequential operations in digital picture processing, J. Assoc. Comput. Mach., 13, 471-494, 1966.

Savic-Jovic, V. and Stevens, B.: The structure and mesoscale organization of precipitating stratocumulus, J. Atmos. Sci., 65, 15871605, 2008.

Seethala, C. and Horváth, Á.: Global assessment of AMSR$\mathrm{E}$ and MODIS cloud liquid water path retrievals in warm oceanic clouds, J. Geophys. Res., 115, D13202, doi:10.1029/2009JD012662, 2010.

Sharon, T. M., Albrecht, B. A., Jonsson, H. H., Minnis, P., Khaiyer, M. M., van Reken, T. M., Seinfeld, J., and Flagan, R.: Aerosol and cloud microphysical characteristics of rifts and gradients in maritime stratocumulus clouds, J. Atmos. Sci., 63, 983-997, 
2006.

Stephens, G. L., Vane, D. G., Boain, R. J., Mace, G. G., Sassen, K., Wang, K., Illingworth, A. J., O'Connor, E. J., Rossow, W. B., Durden, S. L., Miller, S. D., Austin, R. T., Benedetti, A., Mitrescu, C., and the CloudSat Science Team: The CloudSat mission and the A-TRAIN, B. Am. Meteorol. Soc., 83, 1771-1790, doi:10.1175/BAMS-83-12-1771, 2002.

Stephens, G. L., Vane, D. G., Taneli, S., Im, E., Durden, S., Rokey, M., Reinke, D., Partain, P., Mace, G. G., Austin, R., L'Ecuyer, T., Haynes, J., Lebsock, M., Sukuki, K., Waliser, D., Wu, D., Key, J., Gettelman, A., Wang, Z., and Marchand, R.: Cloudsat mission: performance and early science after the first year of operation, J. Geophys. Res., 113, D00A18, doi:10.1029/2008JD009982, 2008.

Stevens, B., Vali, G., Comstock, K., Wood, R., van Zanten, M. C., Austin, P. H., Bretherton, C. S., and Lenschow, D. H.: Pockets of open cells (POCs) and drizzle in marine stratocumulus, B. Am. Meteorol. Soc., 86, 51-57, 2005.

van Zanten, M. C. and Stevens, B.: On the observed structure of heavily precipitating marine stratocumulus, J. Atmos. Sci., 62, 4327-4342, 2005.

Wang, H. and Feingold, G.: Modeling mesoscale cellular structures and drizzle in marine stratocumulus, Part I: impact of drizzle on the formation and evolution of open cells, J. Atmos. Sci., 66, 3237-3256, 2009.

Wentz, F. J. and Meissner, T.: AMSR Ocean Algorithm, Version 2, vol. 121599A-1, Remote Sensing Systems, Santa Rosa, CA, 2000 .
Wentz, F. and Meissner, T.: AMSR-E/Aqua L2B Global Swath Ocean Products Derived from Wentz Algorithm V002, various dates, http://www.nsidc.org/data/amsre, National Snow and Ice Data Center, Boulder, Colorado, USA, 2004.

Westwater, E. R., Han, Y., Shupe, M., and Matrosov, S. Y.: Analysis of integrated cloud liquid and precipitable water vapor retrieval from microwave radiometers during the surface heat budget of the Arctic Ocean project, J. Geophys. Res., 106, 32019-32030, 2001.

Wood, R., Bretherton, C. S., Leon, D., Clarke, A. D., Zuidema, P., Allen, G., and Coe, H.: An aircraft case study of the spatial transition from closed to open mesoscale cellular convection over the Southeast Pacific, Atmos. Chem. Phys., 11, 2341-2370, doi:10.5194/acp-11-2341-2011, 2011a.

Wood, R., Mechoso, C. R., Bretherton, C. S., Weller, R. A., Huebert, B., Straneo, F., Albrecht, B. A., Coe, H., Allen, G., Vaughan, G., Daum, P., Fairall, C., Chand, D., Gallardo Klenner, L., Garreaud, R., Grados, C., Covert, D. S., Bates, T. S., Krejci, R., Russell, L. M., de Szoeke, S., Brewer, A., Yuter, S. E., Springston, S. R., Chaigneau, A., Toniazzo, T., Minnis, P., Palikonda, R., Abel, S. J., Brown, W. O. J., Williams, S., Fochesatto, J., Brioude, J., and Bower, K. N.: The VAMOS Ocean-Cloud-AtmosphereLand Study Regional Experiment (VOCALS-REx): goals, platforms, and field operations, Atmos. Chem. Phys., 11, 627-654, doi:10.5194/acp-11-627-2011, 2011, 2011b.

Zuidema, P., Westwater, E., Fairall, C., and Hazen, D.: Ship-based liquid water path estimates in marine stratocumulus, J. Geophys. Res., 110, D20206, doi:10.1029/2005JD005833, 2005. 